\title{
PROBLEMS OF QUANTIFYING SAVINGS WITHIN ASSET ACQUISITION
}

\author{
Roman Vochozka ${ }^{\mathrm{a}}$, Jaromir Mares ${ }^{\mathrm{b}}$ \\ University of Defence in Brno, Faculty of Military Leadership, \\ Brno, Czech Republic \\ a e-mail: roman.vochozka@unob.cz, \\ ORCID iD: Dhttp://orcid.org/0000-0003-4408-2231 \\ b e-mail: jaromir.mares@unob.cz, \\ ORCID iD: - ittp://orcid.org/0000-0002-1337-3821
}

DOI: 10.5937/vojtehg67-20276; https://doi.org/10.5937/vojtehg67-20276

\begin{abstract}
FIELD: Military Science, Statistics
ARTICLE TYPE: Original Scientific Paper

ARTICLE LANGUAGE: English
\end{abstract}

\begin{abstract}
:
The article describes the application of standard methods of determining savings in the commodity acquisition, which do not impose an obligation to evaluate the centralized award system and the Methodology for the Quantification of Savings set by the Ministry for Regional Development of the Czech Republic. The process is related to the tyres within the Ministry of Defence acquired in the centralized and decentralized manners in the period 2014-2017. In the decentralized manner, higher variability of unit prices and higher variability of the number of suppliers are expected. In the centralized manner, the constant price level is predicted since the supplier is permanent during the whole period of the performance of the framework agreement for a period of two years. Statistical methods - the hypothesis testing method - are used to compare the unit prices in both manners. The comparison has been carried out by the two-sample t-test of the mean values of two selections in order to determine the differences in the amount of financial resources. It has been found that the unit prices of the centralized acquisition are higher than the unit prices of the decentralized acquisition; therefore, the centralized manner of acquisition is more expensive than the decentralized one.
\end{abstract}

Key words: absolute savings, centralized purchase, decentralized purchase, methods, tyres, relative savings, statistics.

\section{Introduction}

Centralized awarding of public contracts is based on the condition that the central bodies of state administration have at least two subordinate organizations in their organizational structure. This condition is satisfied by all ministries of the Czech Republic, i.e. the Ministry of 
Defence of the Czech Republic as well. This implies the obligation to centralize public contracts for the acquisition of commodities according to Annex 2 of The Czech Republic Government Decree No. 24, 2016, irrespective of the expected value of the public contract (Parliament of the Czech Republic, 2016). The commodities concerned are included exhaustively: electricity, gaseous fuels, telecommunications services, office technology and equipment, computers and data processing machines, passenger cars, furniture, and office supplies. The commodities underlying public contracts are subject to a centralized manner of awarding; their estimated value exceeds 2 million CZK (Parliament of the Czech Republic, 2016). This condition is met by most of the public contracts across all public bodies. In the first group of the commodities subject to the centralized awarding of public contracts, there is an obligation to evaluate the departmental systems for the past year, the part of which is quantifying the savings. As for the second group of commodities, the public bodies are not under this duty.

\section{Subject of research}

Tyres as a commodity are a subject of the research within the Ministry of Defence. They are acquired in a centralized manner for the main types of military ground vehicles (TATRA, PANDUR, IVECO, DINGO, UAZ, LANDROVER) and in a decentralized manner for other types of military ground vehicles. It is a very wide range of tyre types and, therefore, the portfolio mentioned has been defined only for the TATRA 815 vehicle type as it creates the largest part of vehicles within the Army of the CR.

\section{Research methods}

The following standard methods (Ministry for Regional Development of the Czech Republic, 2017) have been used to quantify savings: the historic pricing method, the consumption basket method and the benchmark price method.

The historic pricing method lies in comparing the unit prices achieved when purchasing a particular commodity in two different periods. The time period must be the same, usually one calendar year. At the same time, inflation must be taken into account (preferably at the level of a given commodity). The method is suitable for the commodities that are internally poorly structured and the financial volume for the purchase of this commodity can be related to a specific unit of measure, e.g. electricity or natural gas. The advantage is the simplicity of 
calculation and small demands for data logging. The disadvantage is the need to find a common unit of measure and take into account the yearon-year price indices published by the Czech Statistical Office (Czech Statistical Office, 2018). The mathematical relation is given:

- For the relative amount of savings: 1 - (the price for a unit of measure in the current year / the price for a unit of measure in the previous year expressed in the prices of a current year, i.e. adjusted by the year-on-year Consumer Price Index);

- For the absolute amount of savings: the relative amount of savings* the price for a unit of measure in the previous year expressed in the prices of the current year.

- The application of this method is inappropriate for the surveyed tyre.

The consumption basket method lies in comparing the prices at the level of consumption baskets. The commodity as a whole is not investigated, but the price movements over time in selected standard products or services within a given commodity are investigated. The method is commonly used in statistical practice to estimate the changes in price levels. When applying this method, it is always necessary to identify at least three standard commodities that do not change over time (i.e. they are purchased annually, such as telecommunications or office supplies). The advantage is the simplicity of calculation, small demands for data logging and the relative high accuracy of savings, especially for the purposes of comparing the individual departmental systems of the centralized award, if consumption baskets are the same for all of these systems. The disadvantage is the determination of the consumption basket itself since it depends on who determines the consumption basket and in what way. The mathematical relation is given:

- For the relative amount of savings: 1 - (the total price for the consumption basket achieved in the current year / the total price for the consumption basket achieved in the previous year expressed in the current year prices adjusted for the year-on-year Consumer Price Index).

The total price for the consumption basket achieved in the current year will be calculated as the sum of financial volumes of purchases of individual items in the consumption basket and the financial volume of the purchase will be calculated as the product of the quantity purchased in the current year and the prices in the current year. The total price for the consumption basket achieved in the previous year will be calculated as the sum of financial volumes of purchases of individual items in the 
consumption basket and the financial volume of the purchase will be calculated as the product of the quantity purchased in the current year and the prices in the previous year:

- For the absolute amount of savings: the relative amount of savings* the financial volume of the goods acquisition for the previous calendar year expressed in the prices of the current year.

The application of this method to quantify savings for the commodity under investigation may be appropriate.

The benchmark price method lies in comparing the prices of the purchase of specific products or services (i.e. individual items within a particular commodity) with benchmark prices, which are presented as follows:

a) By the list price - the price published on the websites or in the catalogue of the supplier;

b) By the average value of the offer price within the tender;

c) By the average price published on one of the web portals comparing prices in Internet-based shops.

The above-mentioned method assumes that centralization will result in price reductions below "normally quoted market prices". The method can be used with each commodity. The advantage is high accuracy (the comparison with market prices is more accurate than the comparison with historical prices). The disadvantage of the method is the difficult check of saving calculation, which cannot be compared across the individual departmental systems, and the high demands for data logging. The mathematical relation is given:

- For the relative amount of savings: 1 - (the total price for selected products achieved in the current year / the total price for selected products achieved for benchmark prices).

The total price for selected products achieved in the current year will be calculated as the sum of the financial volumes of selected product purchases during the entire current calendar year (if a given product was purchased in the course of the year repeatedly, it is necessary to add up all of these purchases). The total price for selected products achieved for benchmark prices will be calculated as the sum of the financial volumes of selected product purchases and the financial volume of the purchase will be calculated as the product of the quantity purchased in the current year and the average benchmark price: 
- For the absolute amount of savings: the relative amount of savings* (the financial volume of the goods purchase in the current year / (1 - the relative amount of savings).

The application of the method for the commodity under investigation may be limited in 2017 for benchmark prices a) and c) since it is based on the assumption that the prices found on suppliers' websites or the average prices of Internet-based shops do not differ from those in 2017. Benchmark prices b) are not used due to unavailability of the contractual documentation. The above-mentioned methods have also been used to compare the centralized and decentralized manner of acquisition.

The statistical method for hypothesis testing - the two-sample t-test (Neubauer et al, 2016) has been used to compare the unit prices of the centralized and decentralized manner of tyre acquisition for the period 2014-2017, irrespective of the type of vehicles. The mathematical relation is given for the basic test criterion (statistics) as follows:

$$
t=\frac{\bar{d}}{s_{d}} \cdot \sqrt{n}
$$

where

$\bar{d}$ - the arithmetic mean of the differences of both sets,

$S_{d}$ - the standard deviation of the differences of both sets,

$n$ - number of measured unit prices (number of set elements).

It follows from the above-mentioned data that testing the statistical hypotheses is based on the assumption of the probability of dividing the monitored random variable, i.e. null hypothesis $H$, against which an alternative hypothesis $A$ is built. The validity of the null statistical hypothesis is verified based on the selection values. In this case, this is a paired test of two selections, in which the equivalence of the mean values is

$$
H: \mu_{1}=\mu_{2} .
$$

When the null hypothesis $H$ is valid, the test criterion (7) has Student's tdistribution $(v)$ with degrees of freedom

$$
v=n-1 \text {. }
$$


According to the alternative hypothesis, the critical regions $W_{\alpha}$ are selected, where $\alpha$ represents the level of significance - the probability that the null hypothesis will be rejected, most often $\alpha=0.05$ :

$$
\begin{aligned}
& >\mu_{2} \Rightarrow W_{\alpha}\left\{t ; t \geq t_{1-\alpha}(v)\right\}, \\
& A: \mu_{1}<\mu_{2} \Rightarrow W_{\alpha}\left\{t ; \leq-t_{1-\alpha}(v)\right\}, \\
& A: \mu_{1} \neq \mu_{2} \Rightarrow W_{\alpha}\left\{t ;|t| \geq t_{1-\frac{\alpha}{2}}(v)\right\},
\end{aligned}
$$

where $t_{1-\alpha}(v), t_{1-\frac{\alpha}{2}}(v)$ the Student's distribution quantiles are shown in the statistical tables (Neubauer et al, 2016). Based on the calculation of the test criterion $t$ and its comparison with the critical values $t_{1-\alpha}(v), t_{1-\frac{\alpha}{2}}(v)$, a conclusion on the rejection or non-rejection of $H$ will be set, i.e. whether the unit prices of the centralized acquisitions are higher than the unit prices of the decentralized acquisitions.

\section{Results of research \\ Quantification of tyre savings in the centralized manner of acquisition}

Within the quantification of savings for the T-815 tyres acquired in the centralized manner, when comparing unit prices, their mutual agreement in 2014-2015 was found since the supplies during this period were provided by a single supplier. These are agreed prices in the framework agreement, which are constant during the whole period of the performance of the agreement. The comparison of 2015-2016 was not made due to the acquisition of one commodity. A possible comparison was over the years 2015 and 2017 (2017 would be considered the current year). However, this does not correspond to the mathematical relations of the above-mentioned standard methods from the viewpoint of the sequence of the studied periods, i.e. successive years. In this case, the consumption basket method with relations (3) and (4) is used to quantify the savings. The above-mentioned facts are stated in Table 1. 
Table 1 - Overview of the T-815 tyres acquired in the centralized manner in 2015 and 2017

Таблица 1 - Обзор покрышек для Т-815, приобретенных методом централизованной закупки в 2015 и 2017 ге.

Табела 1 - Преглед гума за T-815 набављених централизованим поступком набавке 2015. и 2017. године

\begin{tabular}{|c|c|c|c|c|c|c|}
\hline \multirow{2}{*}{$\begin{array}{l}\text { Period } \\
\text { - year } \\
\begin{array}{l}\text { Type of } \\
\text { tyres }\end{array}\end{array}$} & \multicolumn{3}{|l|}{2017} & \multicolumn{3}{|l|}{2015} \\
\hline & $\begin{array}{l}\text { Quantity } \\
\text { [pcs] }\end{array}$ & $\begin{array}{l}\text { Price for } \\
\mathrm{u} / \mathrm{m}[\mathrm{CZK}]\end{array}$ & $\begin{array}{l}\text { Total price } \\
{[\mathrm{CZK}]}\end{array}$ & $\begin{array}{l}\text { Quantity } \\
\text { [pcs] }\end{array}$ & \begin{tabular}{|l|} 
Price for $u / m$ \\
{$[C Z K]$}
\end{tabular} & Total price $[\mathrm{CZK}]$ \\
\hline $\begin{array}{l}\text { TYRE } \\
12 \\
\text { R22.5 } \\
\text { DM1 } \\
\text { M+S }\end{array}$ & 262 & $7,792.40$ & $2,041,608.80$ & 511 & $8,457.90$ & $4,321,986.90$ \\
\hline $\begin{array}{l}\text { TYRE } \\
12,00 \\
\text { R20 } \\
\text { BS71 } \\
\text { ROAD }\end{array}$ & 168 & $9,105.25$ & $1,529,682.00$ & 199 & $10,043.00$ & $1,998,557.00$ \\
\hline $\begin{array}{l}\text { TYRE } \\
11.00 \\
\text { R20 } \\
\text { NR 55 } \\
\end{array}$ & 282 & $8,385.30$ & $2,364,654.60$ & 296 & $9,196.00$ & $2,722,016.00$ \\
\hline $\begin{array}{l}\text { TYRE } \\
445 / 65 \\
\text { R22.5 } \\
\text { BS49 } \\
\end{array}$ & 210 & $13,479.40$ & $2,830,674.00$ & 451 & $13,673.00$ & $6,166,523.00$ \\
\hline TOTAL & & & $8,766,619.40$ & & & $15,209,082.90$ \\
\hline
\end{tabular}

On the basis of unit prices, it is possible to state that the prices of the items in question in 2015 are higher than those in 2017. The next step includes the conversion of the prices in 2015 to the prices in 2017. The result is illustrated in Table 2.

On the basis of (3), the relative savings in 2017 are 0.39 (i.e. $39 \%$ ) as compared to 2015 and on the basis of relation (4), the absolute savings are equal to $5,588,499.95 \mathrm{CZK}$. In spite of the increasing inflation from 2015 to 2017 by $2.2 \%$ (from $0.3 \%$ to $2.5 \%$ ) (https://www.czso.cz/, nd), the unit prices in 2017 are lower as a result of new lower agreed prices of another supplier for the 2016 - 2018 period of the performance of the agreement. 
Table 2 - Conversion of the prices of the T-815 tyres acquired in the centralized manner in 2015 to the prices in 2017 (the current year)

Таблица 2 - Пересчет цен на шины T-815, приобретенных централизованно в 2015 году, в цены в 2017 году (текущий год)

Табела 2 - Конверзија цена гума за Т-815 набављених 2015. године централизованим поступком набавке у цене из 2017. године (текућа година)

\begin{tabular}{|c|c|c|c|c|c|c|}
\hline \multirow{2}{*}{$\begin{array}{l}\text { Period - } \\
\text { year } \\
\begin{array}{l}\text { Type of } \\
\text { tyres }\end{array}\end{array}$} & \multicolumn{3}{|l|}{2017} & \multicolumn{3}{|l|}{2015} \\
\hline & $\begin{array}{l}\text { Quantity } \\
\text { [pcs] }\end{array}$ & $\begin{array}{l}\text { Price for } \\
\mathrm{u} / \mathrm{m}[\mathrm{CZK}]\end{array}$ & $\begin{array}{l}\text { Total price } \\
{[\mathrm{CZK}]}\end{array}$ & $\begin{array}{l}\begin{array}{l}\text { Quantity } \\
\text { [pcs] }\end{array} \\
\end{array}$ & $\begin{array}{l}\text { Price for } \\
\mathrm{u} / \mathrm{m}[\mathrm{CZK}]\end{array}$ & $\begin{array}{l}\text { Total price } \\
{[\mathrm{CZK}]}\end{array}$ \\
\hline $\begin{array}{l}\text { TYRE } 12 \\
\text { R22.5 DM1 } \\
\text { M+S }\end{array}$ & 262 & $7,792.40$ & $2,041,608.80$ & 511 & $7,792.40$ & $3,981,916.40$ \\
\hline $\begin{array}{l}\text { TYRE } \\
12.00 \text { R20 } \\
\text { BS71 } \\
\text { ROAD }\end{array}$ & 168 & $9,105.25$ & $1,529,682.00$ & 199 & $9,105.25$ & $1,811,944.75$ \\
\hline $\begin{array}{l}\text { TYRE } \\
11.00 \text { R20 } \\
\text { NR 55 }\end{array}$ & 282 & $8,385.30$ & $2,364,654.60$ & 296 & $8,385.30$ & $2,482,048.80$ \\
\hline $\begin{array}{l}\text { TYRE } \\
445 / 65 \\
\text { R22.5 } \\
\text { BS49 }\end{array}$ & 210 & $13,479.40$ & $2,830,674.00$ & 451 & $13,479.40$ & $6,079,209.40$ \\
\hline TOTAL & & & $8,766,619.40$ & & & $14,355,119.35$ \\
\hline
\end{tabular}

In case of benchmark prices, a comparison has been used on the www.heureka.cz web portal. The list prices could not be used due to the unavailability of the said types of tyres in terms of their exact designation on the supplier's web portal. The result of the research is Table 3.

According to relations (5) and (6), relative savings of $13 \%$ and absolute savings of $1,045,468.47$ CZK have been set. The current supplier delivers the tyres of the said types for the lowest prices compared to both 2015 (consumption basket) and benchmark prices; this is illustrated in Table 2 and Table 3. These prices are in relation to 2018 and their current amount may differ from the benchmark prices in 2017. 
Table 3 - Determination of benchmark prices for the T-815 tyres acquired in the centralized manner

Таблица 3 - Определение ориентировочных цен на шины T-815, приобретенных централизованно

Табела 3 - Одређивање цена бенчмаркингом за гуме за T-815 набављене централизованим поступком набавке

\begin{tabular}{|c|c|c|c|c|c|c|}
\hline Period & \multicolumn{3}{|l|}{2017} & \multicolumn{3}{|c|}{ Benchmark price } \\
\hline $\begin{array}{l}\text { Type of } \\
\text { tyres }\end{array}$ & $\begin{array}{l}\text { Quantity } \\
\text { [pcs] }\end{array}$ & $\begin{array}{l}\text { Price for } \mathrm{u} / \mathrm{m} \\
{[\mathrm{CZK}]}\end{array}$ & $\begin{array}{l}\text { Total price } \\
{[\mathrm{CZK}]}\end{array}$ & $\begin{array}{l}\text { Quantity } \\
\text { [pcs] }\end{array}$ & $\begin{array}{l}\text { Price for } \mathrm{u} / \mathrm{m} \\
{[\mathrm{CZK}]}\end{array}$ & $\begin{array}{l}\text { Total price } \\
{[\mathrm{CZK}]}\end{array}$ \\
\hline $\begin{array}{l}\text { TYRE } \\
12 \\
\text { R22.5 } \\
\text { DM1 } \\
M+S\end{array}$ & 262 & $7,792.40$ & $2,041,608.80$ & 262 & $9,181.00$ & $2,405,422.00$ \\
\hline $\begin{array}{l}\text { TYRE } \\
12.00 \\
\text { R20 } \\
\text { BS71 } \\
\text { ROAD }\end{array}$ & 168 & $9,105.25$ & $1,529,682.00$ & 168 & $9,618.00$ & $1,615,824.00$ \\
\hline $\begin{array}{l}\text { TYRE } \\
11.00 \\
\text { R20 } \\
\text { NR 55 }\end{array}$ & 282 & $8,385.30$ & $2,364,654.60$ & 282 & $9,423.00$ & $2,657,286.00$ \\
\hline $\begin{array}{l}\text { TYRE } \\
445 / 65 \\
\text { R22.5 } \\
\text { BS49 }\end{array}$ & 210 & $13,479.40$ & $2,830,674.00$ & 210 & $15,967.00$ & $3,353,070.00$ \\
\hline & & & $8,766,619.40$ & & & $10,031,602.00$ \\
\hline
\end{tabular}

\section{Quantification of tyre savings in the decentralized acquisition manner}

The quantification of savings in the decentralized manner of the T815 tyre acquisition has been aimed at 2014 and 2015 (the current year). The research in other years was not possible since only one common item was acquired both for 2015 - 2016 and for 2016 - 2017. The method selected has been the standard method of the consumption basket again. The following Table 4 provides an overview of the T-815 tyres acquired in the decentralized manner in 2015 most often in the unit price comparison in 2014:

The unit prices of the tyre types examined show higher values in 2015 than in the previous year. A total of 26 cost centres were supplied by three suppliers. In case of TYRE 15.00-21 16PR ET and TYRE 15.00- 
21 MP 913, which were also acquired in the centralized manner, there was only one supplier during that period who delivered the types of tyres for the same unit price to 5 cost centres (in 4 cases TYRE 15.00-21 16PR ET, in 1 case TYRE 15.00-21 MP 913) in 2014.

Table 4 - Overview of the T-815 tyres acquired in the decentralized manner in 2014 and 2015

Таблица 4 - Обзор шин T-815, приобретенных децентрализованно в 2014 и 2015 годаx

Табела 4 - Преглед гума за T-815 набављених децентрализованим поступком 2014. и 2015. године

\begin{tabular}{|c|c|c|c|c|c|c|}
\hline $\begin{array}{l}\text { Period - } \\
\text { year }\end{array}$ & \multicolumn{3}{|l|}{2015} & \multicolumn{3}{|l|}{2014} \\
\hline $\begin{array}{l}\text { Type of } \\
\text { tyres }\end{array}$ & $\begin{array}{l}\text { Quantity } \\
\text { [pcs] }\end{array}$ & $\begin{array}{l}\text { Price for } \\
\mathrm{u} / \mathrm{m}[\mathrm{CZK}]\end{array}$ & $\begin{array}{l}\text { Total price } \\
{[\mathrm{CZK}]}\end{array}$ & $\begin{array}{l}\text { Quantity } \\
\text { [pcs] }\end{array}$ & $\begin{array}{l}\text { Price for } \\
\mathrm{u} / \mathrm{m}[\mathrm{CZK}]\end{array}$ & $\begin{array}{l}\text { Total price } \\
{[\mathrm{CZK}]}\end{array}$ \\
\hline $\begin{array}{l}\text { TYRE } \\
\text { 15.00-21 } \\
\text { 16PR ET }\end{array}$ & 1,582 & $18,798.21$ & $\begin{array}{l}29,738,775.0 \\
0\end{array}$ & 134 & $17,545.00$ & $2,351,030.00$ \\
\hline $\begin{array}{l}\text { TYRE } \\
15.00-21 \\
\text { MP } 913 \\
\end{array}$ & 60 & $18,876.00$ & $1,132,560.00$ & 38 & $17,545.00$ & $666,710.00$ \\
\hline $\begin{array}{l}\text { TYRE } \\
295 / 80 \\
\text { R22.5 } \\
\text { FH1 SI }\end{array}$ & 2 & $8,615.00$ & $17,230.00$ & 6 & $6,413.00$ & $38,478.00$ \\
\hline TOTAL & & & $30,888,565.00$ & & & $3,056,218.00$ \\
\hline
\end{tabular}

In the following year, the supplier increased this price by $7 \%$ on the average and provided supplies to 22 cost centres (TYRE 15.00-21 16PR ET) and 1 cost centre (TYRE 15.00-21 MP 913). In this period, the item of TYRE 295/80 R22.5 FH SI was delivered by two different suppliers to 2 cost centres (one by one in 2014 and in 2015), resulting in a unit price difference.

After the necessary conversion of the prices in 2014 to the prices in 2015, Table 5 has been created.

It is evident from Tables 4 and 5 that the prices of the T-815 tyres acquired in 2015 were higher than those in 2014. The determination of savings has not been implemented since it achieves negative values, i.e. the selected commodity savings in 2015 did not occur in relation to 2014 . The investigation of benchmark prices has not been carried out as the corresponding items of the tyres assessed were not found for the purposes of comparing the prices of Internet- based shops. 
From a global point of view, savings were achieved within the decentralized acquisition of tyres, irrespective of the type of vehicles used only in the comparison of 2015 and 2016 as the current year in the amount of $44 \%$.

Table 5 - Conversion of prices of the T-815 tyres acquired in a decentralized manner in 2014 to the prices in 2015 (the current year)

Таблица 5 - Пересчет цен на шины Т-815, приобретенных децентрализованно в 2014 году, в цены в 2015 году (текущий год)

Табела 5 - Конверзија цена гума за Т-815 набављених 2014. године децентрализованим поступком набавке у цене из 2015. године (текућа година)

\begin{tabular}{|c|c|c|c|c|c|c|}
\hline $\begin{array}{l}\text { Period - } \\
\text { year }\end{array}$ & 2015 & & & 2014 & & \\
\hline Name & $\begin{array}{l}\text { Quantity } \\
\text { [pcs] }\end{array}$ & $\begin{array}{l}\text { Price for } \\
\mathrm{u} / \mathrm{m}[\mathrm{CZK}]\end{array}$ & $\begin{array}{l}\text { Total price } \\
{[\mathrm{CZK}]}\end{array}$ & $\begin{array}{l}\text { Quantity } \\
\text { [pcs] }\end{array}$ & $\begin{array}{l}\text { Price for } \\
\mathrm{u} / \mathrm{m}[\mathrm{CZK}]\end{array}$ & $\begin{array}{l}\text { Total price } \\
{[\mathrm{CZK}]}\end{array}$ \\
\hline $\begin{array}{l}\text { TYRE } \\
\text { 15.00-21 } \\
\text { 16PR ET }\end{array}$ & 1,582 & $18,798.21$ & $29,738,775.00$ & 134 & $18,798.21$ & $2,518,960.71$ \\
\hline $\begin{array}{l}\text { TYRE } \\
15.00-21 \\
\text { MP 913 } \\
\end{array}$ & 60 & $18,876.00$ & $1,132,560.00$ & 38 & $18,876.00$ & $717,288.00$ \\
\hline $\begin{array}{l}\text { TYRE } \\
\text { 295/80 } \\
\text { R22.5 } \\
\text { FH1 SI }\end{array}$ & 2 & $8,615.00$ & $17,230.00$ & 6 & $8,615.00$ & $51,690.00$ \\
\hline TOTAL & & & $30,888,565.00$ & & & $3,287,938.71$ \\
\hline
\end{tabular}

Quantification of tyre savings in the comparison of decentralized and centralized manners of acquisition

When investigating the quantification of savings in the acquisition of the T-815 tyres, the comparison of two successive years is generalized. The comparison is carried out in the whole context of the period 20142017 assessed. The reason is the fact that only one item was left when comparing the acquisition of the tyres for the above-mentioned vehicles in the centralized and decentralized manner. Table 6 illustrates a comparison of the unit prices of both manners of acquiring the commodity concerned.

The data in Table 6 is ranked according to the quantity of the T-815 tyres acquired in the centralized manner and suggests that the centralized manner of acquiring selected items besides TYRE 15.00-21 16PR ET (the commodity in question) in the given period does not bring savings to the relation of decentralized acquisition while using relations (3) and (4). 
The saving values range in negative numbers. After the conversion of unit prices in the decentralized manner of acquisition to unit prices in the centralized manner of acquisition, the absolute savings of the decentralized purchase of the items in Table 6 amounts to 37.09 million CZK, i.e. relative savings of $44 \%$.

Table 6 - Comparison of the unit prices for the $T-815$ tyres in the centralized and decentralized acquisition manners over the period 2014-2017

Таблица 6 - Сравнение цен на единицу продукции: шины T-815 при централизованных и децентрализованных закупках за период 2014-2017 г2.

Табела 6 - Поређење јединичних цена гума за T-815 набављених централизованим и децентрализованим поступцима набавке у периоду 2014-2017. године

\begin{tabular}{|l|l|l|l|l|l|l|}
\hline \multirow{2}{*}{$\begin{array}{l}\text { Name of the } \\
\text { commodity }\end{array}$} & \multicolumn{3}{|l|}{ Centralized manner of acquisition } & \multicolumn{3}{l|}{ Decentralized manner of acquisition } \\
\cline { 2 - 7 } & $\begin{array}{l}\text { Quantity } \\
{[\mathrm{pcs}]}\end{array}$ & $\begin{array}{l}\text { Price for } \\
\mathrm{u} / \mathrm{m}[\mathrm{CZK}]\end{array}$ & $\begin{array}{l}\text { Total price } \\
{[\mathrm{CZK}]}\end{array}$ & $\begin{array}{l}\text { Quantity } \\
{[\mathrm{pcs}]}\end{array}$ & $\begin{array}{l}\text { Price for } \\
\mathrm{u} / \mathrm{m}[\mathrm{CZK}]\end{array}$ & $\begin{array}{l}\text { Total price } \\
{[\mathrm{CZK}]}\end{array}$ \\
\hline $\begin{array}{l}\text { TYRE } \\
\begin{array}{l}15.00-21 \\
16 \mathrm{PR} \text { ET }\end{array}\end{array}$ & 4,384 & $18,521.28$ & $81,197,292.00$ & 2,380 & $18,749.35$ & $44,623,462.22$ \\
\hline $\begin{array}{l}\text { TYRE } \\
\begin{array}{l}12.00-20 \\
\text { 154J M+S }\end{array}\end{array}$ & 58 & $9,922.00$ & $575,476.00$ & 12 & $7,747.03$ & $92,964.36$ \\
\hline $\begin{array}{l}\text { TYRE } \\
\text { 15.00-21 MP } \\
\text { 913 }\end{array}$ & 56 & $21,175.00$ & $1,185,800.00$ & 98 & $18,359.90$ & $1,799,270,00$ \\
\hline $\begin{array}{l}\text { TYRE 11.00 } \\
\text { R20 146K } \\
\text { LET }\end{array}$ & 34 & $9,075.00$ & $308,550.00$ & 6 & $7,320.61$ & $43,923.66$ \\
\hline $\begin{array}{l}\text { TYRE 12 } \\
\text { R22.5 152L } \\
\text { FH1 }\end{array}$ & 32 & $7,852.91$ & $251,293.00$ & 13 & $6,207.30$ & $80,694.90$ \\
\hline TOTAL & & & $83,518,411.00$ & & & $46,640,315.14$ \\
\hline
\end{tabular}

At this point, it should be noted that there is a difference in the costs of acquisition in the whole cycle for both manners of awarding public contracts within the Ministry of Defence when the centralized manner is more expensive in terms of the number of elements involved in the acquisition.

\section{Comparison of unit prices of the centralized and} decentralized acquisition manners

The tyres acquired both by the cost centres themselves and also at the level of the Ministry of Defence have been selected for this study. Table 7 shows the individual items acquired in the two manners in the period 2014-2017, irrespective of the type of vehicles: 
Table 7 - Acquired tyre items between 2014 and 2017 in the centralized and decentralized manners

Таблица 7 - Приобретенные шины за период с 2014 по 2017 год централизованно и децентрализованно

Табела 7 - Гуме набављене у периоду од 2014. до 2017. године централизованим и децентрализованим поступком набавке

\begin{tabular}{c|c|c}
\cline { 2 - 3 } Centralized acquisition & Decentralized acquisition \\
\hline
\end{tabular}

\begin{tabular}{|l|l|l|l|l|l|l|l}
\hline $\begin{array}{l}\text { Name and } \\
\text { Quantity } \\
{[\mathrm{pcs}]}\end{array}$ & $\begin{array}{l}\text { Unit of } \\
\text { measure } \\
{[\mathrm{CZK}]}\end{array}$ & $\begin{array}{l}\text { Total price } \\
{[\mathrm{CZK}]}\end{array}$ & $\begin{array}{l}\text { Quantity } \\
{[\mathrm{pcs}]}\end{array}$ & $\begin{array}{l}\text { Unit of } \\
\text { measure }\end{array}$ & $\begin{array}{l}\text { Total price } \\
{[\mathrm{CZK}}\end{array}$
\end{tabular}

\begin{tabular}{l|l|l|l|l|l|l} 
designation & {$[\mathrm{pcs}]$} & {$[\mathrm{CZK}]$} & {$[\mathrm{CZK}]$} & {$[\mathrm{pcs}]$} & $\begin{array}{l}\text { measure } \\
{[\mathrm{CZK}]}\end{array}$ & {$[\mathrm{CZK}]$}
\end{tabular}

\begin{tabular}{|c|l|l|l|l|l|l|l|l|}
\hline 1 & $\begin{array}{l}\text { TYRE 15.00- } \\
\text { 21 16PR ET }\end{array}$ & 4,384 & $18,521.28$ & $81,197,292.00$ & 6,764 & $18,601.53$ & $125,820,761.00$ \\
\hline
\end{tabular}

TYRE 365/80

2 R20 152K

TYR

3 R22.5 DM1

$\mathrm{M}+\mathrm{S}$

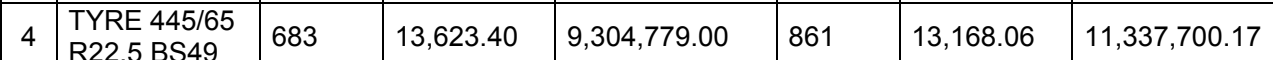

5 R15 99K $\quad 627$

TYRE 11.00

6 R20 NR 55

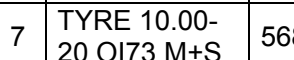

TYRE 12.00

8 R20 BS71 ROAD

TYRE 14.00

9 R20 160G $\mathrm{M}+\mathrm{S}$

\begin{tabular}{|c|c|c|c|c|c|c|c|}
\hline 10 & $\begin{array}{l}\text { TYRE } 7.50 \\
\text { R16 C } \\
116 / 114 \mathrm{~N}\end{array}$ & 379 & $4,235.00$ & $1,605,065.00$ & 937 & $3,902.44$ & $3,656,584.24$ \\
\hline 11 & $\begin{array}{l}\text { TYRE } 8.25-20 \\
\text { 10PR NT } 8\end{array}$ & 312 & $4,505.08$ & $1,405,584.40$ & 4 & $4,719.00$ & $18,876.00$ \\
\hline 12 & $\begin{array}{l}\text { TYRE } 12 \\
\text { R22.5 FM1 } \\
\text { VECTOR }\end{array}$ & 310 & $8,228.00$ & $2,550,680.00$ & 360 & $8,110.36$ & $2,919,730.00$ \\
\hline 13 & $\begin{array}{l}\text { TYRE 205/80 } \\
\text { R16 104T } \\
\text { M+S }\end{array}$ & 192 & $1,996.50$ & $383,328.00$ & 363 & $1,927.29$ & $699,605.06$ \\
\hline 14 & $\begin{array}{l}\text { TYRE 325/85 } \\
\text { R16 137J } \\
\text { XML } \\
\end{array}$ & 164 & $30,719.32$ & $5,037,968.70$ & 183 & $30,636.30$ & $5,606,443.70$ \\
\hline 15 & $\begin{array}{l}\text { TYRE 12.00- } \\
20154 \mathrm{~J} \mathrm{M}+\mathrm{S}\end{array}$ & 58 & $9,922.00$ & $575,476.00$ & 70 & $9,549.15$ & $668,440.30$ \\
\hline 16 & $\begin{array}{l}\text { TYRE 15.00- } \\
21 \text { MP } 913 \\
\end{array}$ & 56 & $21,175.00$ & $1,185,800.00$ & 154 & $19,383.57$ & $2,985,070.00$ \\
\hline 17 & $\begin{array}{l}\text { TYRE } 11.00 \\
\text { R20 146K } \\
\text { LET }\end{array}$ & 34 & $9,075.00$ & $308,550.00$ & 40 & $8,811.84$ & $352,473.65$ \\
\hline
\end{tabular}




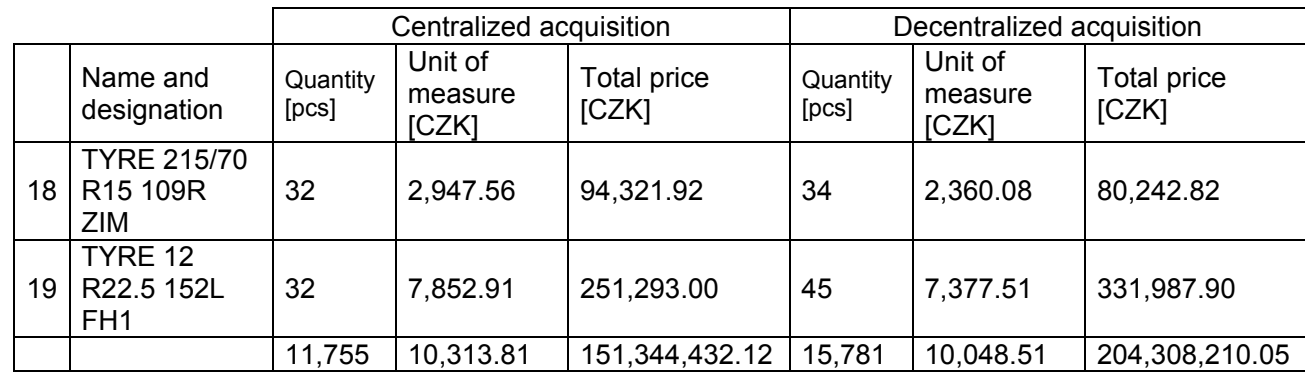

The items in Table 7 are ranked in descending order according to the frequency of the centralized acquisition manner. From the global point of view, it can be stated that the decentralized acquisition manner prevails quantitatively within the above-mentioned items. For the investigation of unit prices when comparing the decentralized and centralized acquisitions, the data were ranked in the descending order according to unit prices, as shown in Table 8.

Table 8 - Unit prices of the tyres acquired in 2014-2017 in the centralized and decentralized manners

Таблица 8 - Поштучная цена на шины, приобретенные за период 2014-2017 г2. централизованным и децентрализованным методами закупок

Табела 8 - Јединичне цене гума набављених у периоду 2014-2017. централизованим и децентрализованим поступком набавке

\begin{tabular}{|l|l|l|l|l|l|}
\hline $\begin{array}{l}\text { Item } \\
\text { number }\end{array}$ & $\begin{array}{l}\text { CENTRALIZED } \\
\text { PURCHASE }\end{array}$ & Unit price & $\begin{array}{l}\text { Item } \\
\text { number }\end{array}$ & $\begin{array}{l}\text { DECENTRALIZED } \\
\text { PURCHASE }\end{array}$ & Unit price \\
\hline 1 & $\begin{array}{l}\text { TYRE 325/85 R16 } \\
\text { 137J XML }\end{array}$ & $30,719.32$ & 1 & TYRE 325/85 R16 137J XML & $30,636.30$ \\
\hline 2 & $\begin{array}{l}\text { TYRE 15.00-21 MP } \\
913\end{array}$ & $21,175.00$ & 2 & TYRE 15.00-21 MP 913 & $19,383.57$ \\
\hline 3 & $\begin{array}{l}\text { TYRE 15.00-21 } \\
\text { 16PR ET }\end{array}$ & $18,521.28$ & 3 & TYRE 15.00-21 16PR ET & $18,601.53$ \\
\hline 4 & $\begin{array}{l}\text { TYRE 14.00 R20 } \\
\text { 160G M+S }\end{array}$ & $17,908.00$ & 4 & TYRE 14.00 R20 160G M+S & $18,006.52$ \\
\hline 5 & $\begin{array}{l}\text { TYRE 445/65 R22.5 } \\
\text { BS49 }\end{array}$ & $13,623.40$ & 5 & TYRE 445/65 R22.5 BS49 & $13,168.06$ \\
\hline 6 & $\begin{array}{l}\text { TYRE 365/80 R20 } \\
\text { 152K MPT }\end{array}$ & $12,574.99$ & 6 & $\begin{array}{l}\text { TYRE 365/80 R20 152K } \\
\text { MPT }\end{array}$ & $12,575.48$ \\
\hline 8 & $\begin{array}{l}\text { TYRE 12.00-20 } \\
\text { 154J M+S }\end{array}$ & $9,922.00$ & 7 & TYRE 12.00-20 154J M+S & $9,549.15$ \\
\hline 9 & $\begin{array}{l}\text { TYRE 12.00 R20 } \\
\text { BS71 ROAD }\end{array}$ & $9,682.49$ & 8 & $\begin{array}{l}\text { TYRE 12.00 R20 BS71 } \\
\text { ROAD }\end{array}$ & $9,180.55$ \\
\hline 10 & $\begin{array}{l}\text { TYRE 11.00 R20 } \\
\text { TY6K LET }\end{array}$ & $9,075.00$ & 9 & TYRE 11.00 R20 146K LET & $8,811.84$ \\
\hline 11 & $\begin{array}{l}\text { NYR 55 } \\
\text { DM1 } 12 \text { R22.5 R20 }\end{array}$ & $8,830.80$ & 10 & TYRE 11.00 R20 NR 55 & $8,751.16$ \\
\hline 12 & $\begin{array}{l}\text { TYRE 12 R22.5 } \\
\text { FM1 VECTOR }\end{array}$ & $8,260.21$ & 11 & TYRE 12 R22.5 DM1 M+S & $8,254.62$ \\
\hline
\end{tabular}




\begin{tabular}{|c|c|c|c|c|c|}
\hline $\begin{array}{c}\text { Item } \\
\text { number }\end{array}$ & $\begin{array}{l}\text { CENTRALIZED } \\
\text { PURCHASE }\end{array}$ & Unit price & $\begin{array}{l}\text { Item } \\
\text { number }\end{array}$ & $\begin{array}{l}\text { DECENTRALIZED } \\
\text { PURCHASE }\end{array}$ & Unit price \\
\hline 13 & $\begin{array}{l}\text { TYRE } 12 \text { R22.5 } \\
\text { 152L FH1 }\end{array}$ & $7,852.91$ & 13 & TYRE 12 R22.5 152L FH1 & $7,377.51$ \\
\hline 14 & $\begin{array}{l}\text { TYRE } 8.25-20 \text { 10PR } \\
\text { NT } 8\end{array}$ & $4,505.08$ & 14 & TYRE 8.25-20 10PR NT 8 & $4,719.00$ \\
\hline 15 & $\begin{array}{l}\text { TYRE } 7.50 \text { R16 C } \\
116 / 114 \mathrm{~N}\end{array}$ & $4,235.00$ & 15 & TYRE 10.00-20 OI73 M+S & $3,923.20$ \\
\hline 16 & $\begin{array}{l}\text { TYRE } 10.00-20 \\
\text { OI73 M+S }\end{array}$ & $3,920.40$ & 16 & TYRE 7.50 R16 C 116/114N & $3,902.44$ \\
\hline 17 & $\begin{array}{l}\text { TYRE 215/70 R15 } \\
\text { 109R ZIM }\end{array}$ & $2,947.56$ & 17 & TYRE 215/70 R15 109R ZIM & $2,360.08$ \\
\hline 18 & $\begin{array}{l}\text { TYRE 205/80 R16 } \\
\text { 104T M+S }\end{array}$ & $1,996.50$ & 18 & $\begin{array}{l}\text { TYRE 205/80 R16 104T } \\
M+S\end{array}$ & $1,927.29$ \\
\hline 19 & $\begin{array}{l}\text { TYRE 215/90 R15 } \\
\text { 99K }\end{array}$ & $1,984.40$ & 19 & TYRE 215/90 R15 99K & $1,683.11$ \\
\hline
\end{tabular}

After arranging the unit prices in the descending order, the order of items acquired in the centralized manner corresponds to the items that were acquired in the decentralized manner, except the items under order numbers 15 and 16 . To calculate the basic test criterion $t$, it is necessary to determine the differences of the individual unit prices of both manners of acquisition, as shown in Table 9.

Table 9 - Expression of the unit price differences of the centralized and decentralized acquisitions

Таблица 9 - Разница в цене при централизованном и децентрализованном методах закупки

Табела 9 - Разлике у јединичним ценама при централизованом и децентрализованом поступку набавке

\begin{tabular}{|l|l|l|l|l|}
\hline $\begin{array}{l}\text { Item } \\
\text { number }\end{array}$ & Name of the item acquired & $\begin{array}{l}\text { Unit of measure of } \\
\text { the centralized } \\
\text { purchase } \\
\left(\mathrm{x}_{\mathrm{i}}\right)[\mathrm{CZK}]\end{array}$ & $\begin{array}{l}\text { Unit of measure } \\
\text { of the } \\
\text { decentralized } \\
\text { purchase } \\
\left(\mathrm{y}_{\mathrm{i}}\right)[\mathrm{CZK}]\end{array}$ & $\begin{array}{l}\text { Difference } \\
\mathrm{d}_{\mathrm{i}} \\
\left(\mathrm{x}_{\mathrm{i}}-\mathrm{y}_{\mathrm{i}}\right) \\
{[\mathrm{CZK}]}\end{array}$ \\
\hline 1 & TYRE 325/85 R16 137J XML & $30,719.32$ & $30,636.30$ & 83.01697 \\
\hline 2 & TYRE 15.00-21 MP 913 & $21,175.00$ & $19,383.57$ & $1,791.429$ \\
\hline 3 & TYRE 15.00-21 16PR ET & $18,521.28$ & $18,601.53$ & -80.2517 \\
\hline 4 & TYRE 14.00 R20 160G M+S & $17,908.00$ & $18,006.52$ & -98.5242 \\
\hline 5 & TYRE 445/65 R22.5 BS49 & $13,623.40$ & $13,168.06$ & 455.3347 \\
\hline 6 & TYRE 365/80 R20 152K MPT & $12,574.99$ & $12,575.48$ & -0.4861 \\
\hline 7 & TYRE 12.00-20 154J M+S & $9,922.00$ & $9,549.15$ & 372.8529 \\
\hline 8 & TYRE 12.00 R20 BS71 ROAD & $9,682.49$ & $9,180.55$ & 501.9408 \\
\hline 9 & TYRE 11.00 R20 146K LET & $9,075.00$ & $8,811.84$ & 263.1587 \\
\hline 10 & TYRE 11.00 R20 NR 55 & $8,830.80$ & $8,751.16$ & 79.63914 \\
\hline 11 & TYRE 12 R22.5 DM1 M+S & $8,260.21$ & $8,254.62$ & 5.593484 \\
\hline
\end{tabular}




\begin{tabular}{|l|l|l|l|l|}
\hline $\begin{array}{l}\text { Item } \\
\text { number }\end{array}$ & Name of the item acquired & $\begin{array}{l}\text { Unit of measure of } \\
\text { the centralized } \\
\text { purchase } \\
\left(\mathrm{x}_{\mathrm{i}}\right)[\mathrm{CZK}]\end{array}$ & $\begin{array}{l}\text { Unit of measure } \\
\text { of the } \\
\text { decentralized } \\
\text { purchase } \\
\left(\mathrm{y}_{\mathrm{i}}\right)[\mathrm{CZK}]\end{array}$ & $\begin{array}{l}\text { Difference } \\
\mathrm{d}_{\mathrm{i}} \\
\left(\mathrm{x}_{\mathrm{i}}-\mathrm{y}_{\mathrm{i}}\right) \\
{[\mathrm{CZK}]}\end{array}$ \\
\hline 12 & TYRE 12 R22.5 FM1 VECTOR & $8,228.00$ & $8,110.36$ & 117.6389 \\
\hline 13 & TYRE 12 R22.5 152L FH1 & $7,852.91$ & $7,377.51$ & 475.3974 \\
\hline 14 & TYRE 8.25-20 10PR NT 8 & $4,505.08$ & $4,719.00$ & -213.922 \\
\hline 15 & TYRE 7.50 R16 C 116/114N & $4,235.00$ & $3,923.20$ & 332.5622 \\
\hline 16 & TYRE 10.00-20 OI73 M+S & $3,920.40$ & $3,902.44$ & -2.79864 \\
\hline 17 & TYRE 215/70 R15 109R ZIM & $2,947.56$ & $2,360.08$ & 587.4771 \\
\hline 18 & TYRE 205/80 R16 104T M+S & $1,996.50$ & $1,927.29$ & 69.21333 \\
\hline 19 & TYRE 215/90 R15 99K & $1,984.40$ & $1,683.11$ & 301.2853 \\
\hline
\end{tabular}

Using the relations of the two-sample t-test (7), the test criterion $t=2.65$ has been determined. Since the values of the Student's distribution quantiles $t_{0.95}(18)=1.734$ and $t_{0.975}(18)=2.101$ are lower than $\mathrm{t}$ and correspond to relations (10) and (12), it can be stated that at the significance level of 0.05 there is a difference between the prices of the centralized and decentralized acquisitions, i.e. the prices of the centralized acquisition are higher.

\section{Conclusions}

The managing body for awarding public contracts within the Ministry of Defence is responsible for quantifying the savings and transferring the data together with the evaluation of the past year to the system administrator. On the basis of the application of the Methodology for the Quantification of Savings using the consumption basket method, it can be stated that in the selected subject of the research there were partial savings in the centralized and decentralized manners of acquisition in the given period.

When comparing the centralized and decentralized acquisitions using the above-mentioned method, it has been found that, for the selected tyre items, partial savings of $44 \%$ were achieved in the decentralized manner. This assertion is also supported by the statistical method of the two-sample t-test of the difference in unit prices of the two manners of acquisition.

Under the current law (http://www.portal-vz.cz/getmedia/abd1a02e3ef8-44a7-9a8c-a06037a6e007/ZZVZI, 2018), it is possible to apply its provisions on operating units that could acquire the given items in a decentralized manner at the estimated value of the public contract over 2 million CZK excluding VAT. The Ministry of Defence has given its approval 
to determine the "operating unit" status. Thus, cost centres could acquire assets with lower cost loads throughout the acquisition cycle flexibly and in compliance with the $3 \mathrm{E}$ principles.

\section{References}

-Czech Statistical Office. 2018. Average annual inflation rate.Prague. [online] (in Czech). Available at: https://www.czso.cz/. Accessed: 01.05.2018.

-Ministry for Regional Development of the Czech Republic. 2017. Methodology of quantifying savings achieved within the centralized system.Prague. [online] (in Czech). Available at: http://www.portalvz.cz/getmedia/249f2971-7640-4d94-b8b1- cea9a4434c88/Metodikavycislovani-uspor-dosazenych-v-ramci-RSCZ_verze-3-2.pdf. Accessed: 25.04.2018.

Neubauer, J., Sedlačík, M., \& Kř́ž, O. 2016. Fundamentals of statistics: Applications in technical and economic fields. Prague: Grada Publishing House.

-Parliament of the Czech Republic. 2016. Act No. 134/2016 Coll. About of Public Procurement, 18 th of April 2016, as amended (in Czech). Available at: http://www.portal-vz.cz/getmedia/abd1a02e-3ef8-44a7-9a8ca06037a6e007/ZZVZ. Accessed: 25.04.2018.

The Czech Republic Government Decree No. 24. 2016. Toward centralized procurement systems following the rules of central purchasing of the state. Prague (in Czech). Available at: http://www.portal-vz.cz/getmedia/940c7136643c-4fbd-8f27-d9acbf68934e/Priloha-c-2-k-UV-c-24-z-18-ledna-2016.pdf.

\section{ПРОБЛЕМЫ КВАНТИФИКАЦИИ ЭКОНОМИИ ПРИ ЗАКУПКАХ}

Роман Вохоска, Яромир Марес

Университет обороны в г. Брно, Факультет военного управления, г. Брно, Республика Чехия

РУБРИКИ: 78.75.00 Военная экономика;

78.75.73 Статистика, учет и отчетность. Техникоэкономический анализ в военном деле

ВИД СТАТЬИ: оригинальная научная статья

ЯЗЫК СТАТЬИ: английский

\section{Резюме:}

В статье описаны стандартные методы определения экономии при приобретении средств, которые не подразумевают обязательную оценку централизованной системы принятия решений, а также методологию квантификации экономии, предписанную Министерством регионального развития Чешской Республики. Данный процесс описан на примере централизованных и децентрализованных закупок шин, приобретенных для нужठ Министерства с 2014 по 2017 год. При децентрализованных 
закупках ожидается большая степень вариабельности как в отношении цены, так и в отношении количества поставщиков. При централизованных закупках предусмотрена постоянность цен, поскольку с поставщиком подписывается договор на двухлетний срок действия. Статистические методы - метод проверки гипотезы был применен для сравнения цен за единицу продукции при закупках обоих видов. Т-критерий был применен для сравнения средних значений двух групп выборок, с целью выявления разницы в количестве фринансовых ресурсов. Было установлено, что цены за единицу при централизованных закупках были выше, чем цены за единицу при децентрализованных закупках. Следовательно, централизованный метод закупок обходится дороже, чем децентрализованный метод.

Ключевые слова: абсолютная экономия, централизованные закупки, децентрализованные закупки, методы, шины, относительная экономия, статистика.

ПРОБЛЕМИ КВАНТИФИКАЦИЈЕ УШТЕДЕ ПРИЛИКОМ НАБАВКЕ СРЕДСТАВА

Роман Вохоска, Јаромир Марес

Универзитет одбране у Брну, Факултет војног руковођења,

Брно, Чешка Република

ОБЛАСТ: војне науке, статистика

ВРСТАЧЛАНКА: оригинални научни рад

ЈЕЗИКЧЛАНКА: енглески

Сажетак:

У раду се описује примена стандардних метода одређивања уштеде при набавци средстава која не намећу обавезу евалуације централизованог система одлучивања и методологије за квантификацију уштеде коју је прописало Министарство регионалног развоја Републике Чешке. Описани процес односи се на гуме набављане централизованим и децентрализованим поступком за потребе Министарства одбране у периоду 2014-2017.године. При децентрализованом поступку очекује се виша варијабилност, како код јединичних цена, тако и код броја снабдевача. При централизованом поступку предвиђа се константни ниво цене, јер је снабдевач исти током иелог договореног периода снабдевања од две године. Статистичке методе - методе тестирања хипотезе користе се за поређење јединичних цена у оба поступка. Коришћен је m-тест два узорка за поређење просечних вредности две групе узорака како би се одредила разлика у 
количини фринансијских извора. Утврђено је да су јединичне цене центализоване набавке више од јединичних цена децентрализоване набавке, па се може закључити да је централизовани поступак набавке скупљи од децентрализованог.

Кључне речи: апсолутна уштеда, централизована набавка, децентрализована набавка, методе, гуме, релативна уштеда, статистика.

Paper received on / Дата получения работы / Датум пријема чланка: 23.01.2019.

Manuscript corrections submitted on / Дата получения исправленной версии работы / Датум достављања исправки рукописа: 08.02.2019.

Paper accepted for publishing on / Дата окончательного согласования работы / Датум коначног прихватања чланка за објављивање: 10.02.2019.

(c) 2019 The Authors. Published by Vojnotehnički glasnik / Military Technical Courier (www.vtg.mod.gov.rs, втг.мо.упр.срб). This article is an open access article distributed under the terms and conditions of the Creative Commons Attribution license (http://creativecommons.org/licenses/by/3.0/rs/).

(c) 2019 Авторы. Опубликовано в «Военно-технический вестник / Vojnotehnički glasnik / Military Technical Courier» (www.vtg.mod.gov.rs, втг.мо.упр.срб). Данная статья в открытом доступе и распространяется в соответствии с лицензией «Creative Commons» (http://creativecommons.org/licenses/by/3.0/rs/).

(C) 2019 Аутори. Објавио Војнотехнички гласник / Vojnotehnički glasnik / Military Technical Courier (www.vtg.mod.gov.rs, втг.мо.упр.срб). Ово је чланак отвореног приступа и дистрибуира се у складу са Creative Commons licencom (http://creativecommons.org/licenses/by/3.0/rs/).

\section{(c) (i)}

